\title{
Multiliteration and Higher Order Thinking Skills Implications to Education
}

\author{
Tatang Syaripudin \\ Indonesian Education University, Bandung, Indonesia \\ e-mail: tatangsy@upi.edu
}

\begin{abstract}
This paper aims to describe multiliteration and higher order thinking skills (HOTS) as challenges for 21 st century society, as well as their implications to education. 21st century civilization has triggered the development of the meaning of literacy into multiliteration, and requires the public to have cognitive process skills that are classified as higher order thinking skills. Based on analysis of implications, multiliteration and higher order ranking skills have implications to education. Especially in developing thinking process skills, the purpose of education should be directed at developing cognitive process skills at levels C2 through C6. The curriculum is ideally holistic, integrative, child centered and activity centered. The learning approach is student-centered and applies heuristic strategies. In its implementation, it is necessary to apply various models and/or learning methods that require students to do problem solving, think creatively, and cooperate. The teacher acts as a guide and facilitator rather than as an instructor. 21 st century teachers ideally have characteristics: permissive, friendly, a guide, open-minded, enthusiastic, creative, socially aware, alert, patient, cooperative and sincere
\end{abstract}

Keywords: Implications, multiliteration, higher order thinking skills, education.

\section{Introduction}

Heraclitus (536-470 BC) is famous for its credo "panta rhei" (everything flows, everything does not settle, everything keeps changing). Changes continue, for example, civilization has changed. Although it does not take place linearly in every place and society, the phenomenon shows that civilization has developed starting from primitive, agrarian, industrial civilization, and in the 21 st century to information civilization.

The 21 st century we have passed almost two decades, the future state of society - that is, in the next eight decades - we have not yet experienced and contains various possibilities. As we understand, education is held not only to facilitate the younger generation to exist and live at this time, but also so that the younger generation can exist, live and have a career in the future. Therefore, the condition of the future society that contains various possibilities must be understood as a challenge that needs to be studied and planned. In the context of education, we need to study and anticipate the condition of this 21 st century society along with its implications for education.

Problems regarding the implications of multiliteration and higher order thinking skills for education include two main questions. First, what is the meaning of multiliteration and higher order thinking skills as a challenge for 21 st century society? Second, what are the implications of multiliteration and higher order thinking skills for 
education? This second question covers the implications of it: 1) educational goals, 2) curriculum, 3) learning methods, 4) the role of teachers and teacher characteristics in the 21 st century.

This paper aims to: first, describe the skills that people need to have in the $21 \mathrm{st}$ century. Second, describe the meaning of multiliteration and higher order thinking skills as challenges that arise in 21 st century society. Third, describe the implications of multiliteration and higher order thinking skills in education.

The state of the future society is learned through future research as a historical application (Noer and Alisyahbana, 1988). There are two assumptions used in future research, namely "the principle of continuity" and "principle of analogy" in the development of civilization. Starting from these two assumptions, the futurist uses his abilities holistically to carry out extrapolation trends. In this context, activities that are very related and similar to forecasting are goal setting and planning. Goal setting is the activity of predicting a possible target of various kinds of possibilities that are most likely to occur in the future, while planning is the activity of compiling a sequence of actions in an effort to reach the target (Kurniasih, 2014).

\section{21st Century Skills}

In general it can be described that community civilization has developed through primitive civilizations, agrarian societies, industrial societies, and information societies. The information society became a label for 21 st century society, partly because in this century the phenomenon of digital society emerged. In the context of the development of civilization, challenges in life and career continue to experience changes. In line with this, the skills that must be owned by the community at every stage of development society: primitive, agrarian, industrial, and information - of course different too.

Trilling and Fadel (2009) identify skills that must be owned by the community in the 21 st century. These skills are:

1. Learning and innovation skills. This includes skills: a. critical thinking and problem solving; b. creativity and innovation; c. communication and collaboration.

2. Digital literacy skills. These include: media literacy and ICT literacy

3. Life skills and career. These include flexible and adaptive initiative abilities, social skills in intercultural interactions, productive and accountable leadership, and responsibility.

In order to exist, live and have a good career, the various 21 st century skills that have been identified by Trilling and Fadel are ideally mastered by today's society and society in the coming decades. To master these skills, of course, must be cultivated through education. Multiliteration and Higher Order Thinking Skills

\subsubsection{Multiliteration}

The development of science and technology that helped determine the 21 st century civilization has implications for the meaning of literacy. The definition of literacy continues to evolve, starting from a narrow definition moving to a broader definition.(Hartati, 2016) defines literacy narrowly, namely as the ability to read and 
write. The Education Development Center (Hartati, 2019) defines literacy broadly, namely as the individual's ability to use all the potential and skills possessed in his life.

Abidin (2015) describes the development of literacy meanings in five stages or five genres. In the first stage (first generation), literacy is defined as the ability to use language and images in a rich and varied form to read, write, listen, speak, see, present, and think critically about ideas. As for the final stage (fifth generation), in line with the development of ICT, literacy has developed into multiliteration, namely skills using various ways to express and understand ideas and information using conventional text forms as well as innovative texts, symbols and multimedia.

In accordance with the concept of multiliteration, in the context of the National Literacy Movement (NLM), the Ministry of Education and Culture (Kemendikbud) identified six types of literacy, namely:
a. Language and Literary Literacy.
b. Numeration Literacy.
c. Science Literacy.
d. Digital Literacy.
e. Financial Literacy.
f. Culture and Citizenship Literacy.

\subsection{Higher Order Thinking Skills}

21 st century skills that are expected to be owned by the community, basically in line with the multiliteration that is also expected to be owned by the community. If we analyze it, the skills and / or multiliteration in the acquisition and its application demand cognitive process skills that are classified as higher order thinking skills.

In the context of education, the goals of education contain the cognitive process skills. Category categories in cognitive processes have even been structured in a taxonomy of educational objectives. This is as compiled by Bloom (1956) and revised by Anderson (Anderson, et al, 2001).

Anderson et al (2001: 67-68) describe the categories of cognitive processes in a structured manner as follows:

1) Remember $(\mathrm{C} 1$.

2) Understand (C2).

3) Apply (C3).

4) Analize (C4).

5) Evaluate (C5).

6) Create (C6).

Each of these categories consists of two or more more specific cognitive processes, all of which are 19 and are described in the form of verbs. Based on the characteristics of cognitive processes, then education experts classify cognitive process categories into two, namely low order thinking skills (LOTS), namely $\mathrm{C} 1$, and higher order thinking skills (HOTS), namely C2 to C6. 


\subsection{Multiliteration and HOTS Implications to Education}

In the context of the 21 st century civilization, what is called multiliteration and higher order thinking skills develops. In order for students to be able to exist, live and have a decent career, these two things need to be realized through education. Therefore, so that education can be held in accordance with expectations, the learning must be carried out by taking into account the implications of multiliteration and higher order thinking skills to education.

Based on the analysis that has been done, it can be described the implications of literacy and higher order thinking skills to education. This includes the implications to the purpose of education, curriculum, methods, the role of the teacher and the characteristics of 21 st century teachers.

First, the implications of multiliteration and higher order thinking skills towards the purpose of education are that education should prioritize the direction of developing cognitive process skills at levels C2 through C6.

Second, especially in elementary schools, the curriculum is ideally holistic and integrative. The contents of the curriculum are tailored to the learning objectives to be achieved. The curriculum is ideally child centered and activity centered.

Third, the learning approach is ideally centered on students and applies heuristic strategies. In its implementation, it is necessary to apply various models and / or learning methods that require students to do problem solving, think creatively, and cooperate in learning. Examples: inquiry and discovery, problem based learning, project based learning, cooperative learning, etc.

Fourth, to develop multiliteration and higher order thinking skills, the teacher ideally acts as a guide and facilitator rather than as an instructor. As identified by Syaripudin and Kurniasih (2015) and suggested by philosophers of pragmatism, to facilitate students, the teacher must play a role to:

1) Providing various experiences that will bring motivation.

2) Guiding students in formulating specific problem boundaries.

3) Guiding formulating individual and group goals in class to be used in solving problems.

4) Helping students to gather information regarding problems.

5) Together the class evaluates what has been learned; how they learn it; and what new information students get.

In practice, multiliteration and higher order thinking skills require 21 st century teachers who have the following characteristics: permissive, friendly, a guide, openminded, enthusiastic, creative, socially aware, alert, patient, cooperative and sincere (Callahan and Clark, 1983).

\section{Conclusion}

Society continues to change, 21 st century civilization has different characteristics than civilization in previous centuries. The skills that must be owned by 21 st century society are different from the skills that must be possessed by society in previous centuries. 21 st century civilization has encouraged the development of the meaning of 
literacy to be multiliteration. In addition, it has also triggered the importance of the public having a higher order thinking skills.

In the context of education, 21st century skills, multiliteration and higher order thinking skills are basically challenges that must be addressed immediately. Education should be adapted according to these challenges. Based on an analysis of the implications, multiliteration and higher order ranking skills triggered by 21 st century civilization have implications to education. The implications are: 1) Especially in developing thinking process skills, the purpose of education should be directed at developing cognitive process skills at levels C2 through C6. 2) The curriculum is ideally holistic and integrative, child centered and activity centered. 3) The learning approach is centered on students and applies heuristic strategies. In its implementation, it is necessary to apply various models and/or learning methods that require students to do problem solving, think creatively, and cooperate in learning. 4) The teacher ideally acts as a guide and facilitator rather than as an instructor. 21 st century teachers ideally have the following characteristics: permissive, friendly, a guide, open-minded, enthusiastic, creative, socially aware, alert, patient, cooperative and sincere.

\section{Bibliography}

[1] Abidin, Y. (2015). Pembelajaran Multiliterasi: Sebuah Jawaban atas Tantangan Pendidikan Abad 21 dalam Konteks Keindonesiaan. Bandung. PT. Refika Aditama.

[2] Anderson, L. W. et al (Ed.). (2001). A Taxonomy for Learning, Teaching, and Assesing: Revision of Bloom's Taxonomy of Educational Objective. New York. Addison Wesley Longman Inc.

[3] Callahan, J. F. and Clark, L. H. (1983). Foundations of Education, New York, Macmillan Publishing Co. Inc.

[4] Hartati, T. (2016). Laporan Penelitian Fundamental. Optimalisai Manajemen Berbasis Sekolah Dasar (MBS) untuk Membangun Kelas Literasi dan Kemampuan Multiliterasi Siswa Sekolah Dasar. Bandung. UPI.

[5] Hartati, T. (2019). Pedagogi Bahasa dari Perspektif Multiliterasi dan Keterampilan Berpikir Tingkat Tinggi di Sekolah Dasar (Pidato Pengukuhan Guru Besar). Bandung, UPI.

[6] Kurniasih. (2014). Implikasi Keadaan Masyarakat Abad XXI Terhadap Pendidikan (dalam Prosiding Seminar Internasional Serantau: Pendidikan Abad $\mathrm{Ke}-21)$.

[7] Noer, D. dan Alisyahbana, I. (1988). Perubahan, Pembaharuan dan Kesadaran Menghadapi Abad Ke-21. Jakarta: PT. Dian Rakyat.

[8] Syaripudin, T. dan Kurniasih. (2015). Pengantar Filsafat Pendidikan. Bandung. Percikan Ilmu.

[9] Trilling, B. dan Fadel, C. (2009). 21 ${ }^{\text {st }}$ Century Skills: Learning for Life in Our Times. San Francisco: Jossey-Bass A Wiley Imprint. 